\title{
4 Conflict and displacement in Burma/Myanmar
}

\section{Ashley South}

Patterns of forced migration in Burma/Myanmar are structured by the changing nature of conflict in the country. While acutely vulnerable internally displaced persons do live in those few areas of the country that are still affected by significant armed conflict (especially in the insurgentprone eastern borderlands), the phenomenon of forced migration is more widespread and complex. Yet assessments of forced migration in the country as a whole have tended to be obscured by the focus on parts of eastern Burma that are accessible to agencies working across the border from Thailand. Much less is known about the situation in other geographic areas, or about displaced populations not accessible to the armed opposition groups with which cross-border aid agencies cooperate. Another problem is that the literature on the political economy of conflict and displacement is sparse, and the majority of investigators have been constrained by their own sociopolitical agendas. Their emphasis on 'problem-finding' has not taken account of the positive trends that have emerged in the past decade.

This chapter attempts to redress the balance of existing research by addressing forced migration in parts of the country that are not readily 
accessible from the Thai-Burma border. It identifies new forms of forced migration that have emerged with the existence of cease-fires in many previously armed conflict-affected areas-which could be expected to occur in other affected areas if or when insurgency ends along the border. A better understanding of the situation in areas that are no longer affected by armed conflict could help to prepare local and international actors for future developments in areas that are currently beset by the State's counter-insurgency operations. In many situations, migration itself constitutes a coping mechanism-as illustrated by the variety of rezones labelled 'economic migration'. Towards this end, the study incorporates rights-based perspectives, but also adopts an actororiented perspective, focusing on the agency of displaced people rather than viewing them as passive victims. It seeks to identify the positive responses of individuals and communities to the problems they face.

\section{Terminology and typology}

In this chapter, forced migration is conceptualised as a subset of population movement in general, and internal displacement is a division of forced migration. The Guiding Principles on Internal Displacement (UNHCR 1998) define internally displaced persons as 'persons or groups of persons who have been forced or obliged to flee or to leave their homes or places of habitual residence, in particular as a result of or in order to avoid the effects of armed conflict, situations of generalised violence, violations of human rights or natural or human-made disasters, and who have not crossed an internationally recognised State border' (UNHCR 1998).

This chapter identifies and describes three main types of forced migration in and from the country, each of which is presented with reference to material drawn from different geographic areas (Table 4.1).

The first type is armed conflict-induced displacement, which occurs either as a direct consequence of fighting and counter-insurgency operations or because armed conflict has directly undermined human 
Table 4.1 Typology of forced migration

Internally displaced persons

Type 1

Armed conflict-induced
Other forced migrants

Type 2

Type 3

State-society conflict-induced (post-armed conflict)
Livelihoods vulnerability-induced ('distress migration')

and food security. Type One forced migration is linked to severe human rights abuses across Karen State, in eastern Tenasserim Division, southern Mon State, southern and eastern Karenni State, southern Shan State and parts of Chin State and Sagaing Division.

The second type is state-society conflict-induced displacement, which is generally post-armed conflict and caused by military occupation and or 'development' activities. Type Two forced migration could be due, for example, to land confiscation by the Tatmadaw (military) or other armed groups, or it could be caused by infrastructure construction. It could also be a product of predatory taxation, forced labour and other abuses. All of the border states and divisions are affected by militarisation and/or development-induced displacement, including Arakan (Rakhine) and Kachin States, as well as many urban areas. Type One and Type Two forced migrants are internally displaced persons whose displacement is the result of conflict — either active, armed (Type One) or latent conflict, or the threat of the use of force (Type Two).

A third type is livelihood vulnerability-induced displacement, which is the primary form of internal and external migration in and from Burma. Main causes include inappropriate government practices and policies, limited availability of productive land, poor access to markets resulting in food insecurity, lack of education and health services and stresses associated with transition to a cash economy. Type Three displacement occurs across the country, especially in remote townships. Type Three movements involve a particularly vulnerable subgroup of 
economic migrants and result from limited choices faced by marginal populations. As such, they constitute a form of forced migration. Migration due to opium-eradication policies is included under Type Three because the causes of the movement are related to livelihood issues; with the exception of some Wa areas, people are not ordered to move (opium eradication-induced migration could, however, also be considered under Type Two forced migration, due to the forcible nature of the opium bans, the severe shock to livelihoods involved and the links to development activities).

There are important links between these three types of displacement, each of which undermines traditional livelihood options and depletes people's resource base. Type One characterises zones of continuing armed conflict and some adjacent areas; Type Two is particularly prevalent in remote and underdeveloped conflict-affected areas where cease-fires have been agreed, and also affects urban relocatees; Type Three is characteristic of remote areas, particularly those where armed conflict has ceased. This progression in causes of population movement is not strictly linear: many people are in cyclical transition between different phases of displacement and could be categorised in different ways at different times.

\section{Internally displaced persons: population estimates}

For many Burmese citizens, patterns of often cyclical migration involve periods spent as labourers in other countries and/or more extended periods as refugees in neighbouring countries. The causes and other aspects of population movements within Burma (internal migration) and beyond its borders (external migration) are closely linked and often relate to serious and systematic abuses of a range of basic rights. This chapter focuses primarily on the situation of forced migrants inside Burma.

It is difficult to assess the numbers of internally displaced persons and the scale of the problem. Counting only people who have been forcibly displaced since 2004, the number of internally displaced 
persons in eastern Burma will be no more than 100,000 (including 25,000 people displaced by the Tatmadaw in northern Karen State, since February 2006). The number of previously displaced persons for whom no durable solution has been found must, however, be calculated in the millions. Since 1996, more than 2,800 villages are known to have been destroyed and/or relocated en masse, or otherwise abandoned, due to tatmadaw activity-including at least 306 villages between 2002 and 2005 alone (TBBC 2005b). While unknown numbers of these villages have since been resettled, most remain depopulated. According to the Thailand Burma Border Consortium (TBBC) and its local partner groups, there were 540,000 internally displaced persons in eastern Burma in mid to late 2005. These figures do not include Type One internally displaced persons who choose not to make themselves available to armed opposition groups, or large numbers of people who have achieved at least semi-durable solutions to their plight. Nor do they include the hundreds of thousands of Type Two and Three internally displaced persons in other parts of Burma.

Long-term patterns of displacement have tended to be underresearched, but warrant attention because they are crucial to understanding the dynamics of conflict and patterns, impacts of and responses to forced migration in Burma. Armed conflict-induced (Type One) displacement often occurs among communities that periodically shift their location for sociocultural reasons and/or to access agricultural land. The scale of displacement in Karen and other areas in the past 50 years has, however, been out of all proportion to any traditional patterns of migration. Furthermore, forced migration among significant segments of the Karen and other ethnic nationality communities is not a one-off phenomenon. Rarely do individuals, families or communities return in a simple manner to their original location, which could have come to be occupied by the Tatmadaw or other hostile groups, resettled by other displaced people and/or planted with land-mines. Indepth interviews conducted in 2003-04 with a group of 36 internally displaced Karen in the Papun Hills in northeastern Karen State revealed that many had undergone more than 1,000 migration episodes. Five 
had been forcibly displaced more than 100 times, some dating back to the 1940s. The majority of migration episodes followed directly from fighting, because of severe human rights abuse or because armed conflict had directly undermined sustainable forms of agriculture. I consider the situation of the Karen in the following case study.

Type One forced migration: the Karen

For more than half a century, life across much of rural Burma has been profoundly affected by armed conflict. In many ethnic minoritypopulated areas, repeated incidents of forced displacement-interspersed with occasional periods of relative stability-have been a fact of life for generations. Those cases in which human displacement occurs as a direct result of armed conflict can be classified as Type One forced migration. The situation of the Karen provides an illustration of armed conflict-induced displacement.

The Karen community consists of a diverse collection of ethnolinguistic groups, which nevertheless share a number of common characteristics. At least two-thirds of the five to seven million Karen in Burma are Buddhists. Many of the conceptions of ethnic identity in contemporary Burma remain rooted in the pre-colonial past and in the often traumatic colonial experience (Thant 2001). The Karen ethnonationalist movement emerged during the British colonial period, when Christian Karen élites first began to express the idea of a Karen nation, including all elements of the diverse socio-linguistic community. The Karen National Union (KNU), which went underground in January 1949, was from the outset led by educated Christian élites-in the name of all Karen. In successive years, the rebellion continued as a response to the repressive policies of successive governments in Yangon, and the perceived 'Burmanisation' of the State (Smith 1999).

In the decade after 1962, when General Ne Win's Tatmadaw took control of the country, the KNU and other ethnic insurgent groups received new injections of recruits from government-controlled Burma. Ne Win's disastrous 'Burmese way to socialism' also provided the insurgents with new sources of funds, as the economy collapsed and 
became dependant on smuggled goods_-most of which came from neighbouring Thailand. The KNU and other armed ethnic groups taxed the black-market trade, allowing several rebel leaders to prosper and build up well-equipped armies. Meanwhile, the KNU and other insurgent 'liberated zones' took on some of the characteristics of de facto states, with military and parallel civilian administrations, and health and education systems.

This period saw the emergence of significant economic agendas in the prosecution of armed conflict in Burma. These are epitomised by the rise of the KNU's General Saw Bo Mya, a tough field commander, staunch Christian and anti-communist, who became a key asset in Thai and US strategy in the region. Like most ethnic insurgent groups, the KNU has claimed to be fighting for democracy in Burma-especially since the 1988 democracy uprising. This position has been reflected in a series of alliances struck with pan-Burma opposition groups which fled to the border areas after the events of 1988 and 1990. The democratic ideal has not, however, always been honoured in practice, and the liberated zones have often been characterised by a top-down tributary political system, aspects of which recall pre-colonial forms of sociopolitical organisation. While General Bo Mya et al. have certainly been inspired in their conflict with the central government by genuine and strongly held grievances, many insurgent commanders and their families have also benefitted financially from protracted armed conflict in Burma-especially from the taxation of black-market trade, and from natural resource extraction (in the case of the KNU, logging and mining activities).

Under General Bo Mya, S'ghaw-speaking élites from the lowlands began to unify_and dominate-Karen society in the eastern hills. This internal colonisation had unforeseen consequences, as an underclass of mostly Buddhist subalterns came to resent the domination of an increasingly corrupt and authoritarian alien élite. The end result was rebellion within the Karen nationalist ranks and the formation of the Democratic Kayin Buddhist Army (DKBA) in late 1994 (Smith 1999). 
During the early 1980s, government forces gained the upper hand in the civil war and the first semi-permanent Karen refugee camps were established in Thailand, as civilians (and rebel soldiers) fled tatmadaw offensives along the border. By 1994, with the fall of its headquarters at Mannerplaw, the KNU was in serious trouble. The crisis was compounded by the loss of most of the remaining Karen liberated zones (in southern Karen State and Tennasserim Division) during a major dry-season tatmadaw offensive in 1997.

The KNU today is a greatly weakened force and no longer represents a significant military threat to the State Peace and Development Council (SPDC). The Karen National Liberation Army (KNLA) still has some $5-7,000$ soldiers, deployed in seven brigades (including mobile battalions and village militias), and more than 1,000 active political cadres (including youth and women's wings). At any one time, however, about half of these personnel are located among the 148,000 refugees living in 10 camps (seven Karen, two Karenni, one Shan) in Thailand.

Although the KNU is in danger of becoming marginalised on the Burmese political stage and as an arbiter of Karen affairs, its continuing symbolic importance cannot be denied. The KNU is the oldest and, to many Karen people and Burma watchers, the only legitimate Karen ethno-nationalist group. Having fought for independence (and later, autonomy) from Yangon since 1949, and not having followed other armed ethnic groups into the cease-fire movement, the KNU retains strong credibility in opposition circles.

After more than half a century, armed conflict in Burma has thus become institutionalised and associated with deep-rooted political economies. Commanders on both sides of the front lines (including those, such as the DKBA, which have agreed cease-fires with the government) often rely on the taxation of black-market goods, extraction of natural resources (logging and mining) and other unregulated practices (including the drug trade) to enrich themselves and their retinues, and to support the armed groups, control of which brings the power to extract further 'tribute' and political power-a vicious circle. 
The prevalence of such greed-based models of conflict worldwide tends to provoke scepticism of élite claims to represent ethnic communities. This is especially the case among international agencies and observers with experience of armed conflict and its impacts in other parts of the world, who tend to focus on greed models and the political economy of conflict in Burma. Such perspectives, however, under-appreciate the (often contested) legitimacy of many insurgent and cease-fire groups and underestimate the levels of support they enjoy in their constituencies. In contrast, opposition supporters (especially those based outside Burma) tend to emphasise the struggle against a repressive regime and 'justice/legitimate grievance' models of conflict, and are often supportive of élite-generated ethno-nationalist agendas, without questioning whose interests they serve.

Burma's ethnic insurgent groups have positioned themselves as the defenders of minority populations against the aggression of state forces. They have adopted guerrilla-style tactics, which have invited retaliation against the civilian population, but against which the armed groups have been unable to defend villagers. Since the 1960s, in response to protracted insurgencies in most ethnic nationality-populated areas, state forces have pursued often brutal counter-insurgency strategies, including the forced relocation of civilian populations deemed sympathetic to armed ethnic and communist groups (Taylor 1985). The KNU and other insurgent groups have an interest in controlling, or at least maintaining, civilian populations in traditional Karen lands - as a source of legitimacy, and of food, intelligence and soldiers, porters and so on. Therefore, KNU cadres regularly organise village evacuations to 'protect' villagers from tatmadaw incursions (a service that is appreciated by many internally displaced persons). Clearly, the $\mathrm{KNU}$ and other insurgent organisations bear some responsibility for the plight of civilians in areas where they operate. For nearly 60 years, they have pursued an armed conflict against the central government, although the possibility of any military victory probably disappeared during the 1970s —or, at the latest, after the fall of the last KNU liberated zones in the mid 1990s. 
Such complexities notwithstanding, most forms of forced displacement—and associated serious human rights abuses—still occur in the context of the Tatmadaw's 'four cuts' counter-insurgency strategy (and, more recently, as a result of the activities of government-aligned militias). Having issued orders to relocate to areas firmly under state control, tatmadaw columns often return to remote areas that have been 'cleared' to ensure that they are not resettled (which they often are): many villages are therefore 'serially displaced'.

It is therefore not surprising that armed conflict and counterinsurgency operations in rural Burma have severely disrupted traditional ways of life. Most of the rural and peri-urban population of eastern Burma has been displaced or otherwise affected at some point during the past 50 years. Since the late 1980s, several hundred thousand internally displaced persons have been forced to flee their homes and live under difficult conditions in zones of continuing armed conflict or in government-controlled relocation sites. While some of these people have achieved a level of stability in their new settlements, many have yet to find durable solutions to their plight.

Pockets of relative stability: the KNU cease-fire

After an aborted series of meetings in the mid 1990s, cease-fire negotiations between the SPDC and the KNU began in December 2003 with the announcement of a 'gentleman's agreement' to cease fighting. Although substantial talks began in January the next year, the purge of the relatively progressive prime minister (and military intelligence chief) General Khin Nyunt, in October 2004, presented a serious set-back to the peace process. If the provisional KNU-SPDC cease-fire can be consolidated, it could yet deliver a substantial improvement in the human rights situation on the ground, creating the space in which local and international organisations can begin to address the urgent needs of a war-ravaged population. Since early 2006, however, the Tatmadaw has launched major operations against the civilian population and a diminished KNU insurgency across northern Karen State. 
Between February and December 2006, some 25,000 people were displaced by tatmadaw attacks on villages in northwest Karen State (Toungoo and northern Nyaunglebin Districts, and parts of Papun District-KNLA second, third and fifth brigades). In addition, since April, dozens of villages have received orders from the Tatmadaw to relocate to new settlements in areas more firmly under government control.

Recent tatmadaw offensives in Karen areas (especially in Papun District) seem designed in part to gain control of previously contested areas, in order to undertake major infrastructure developments, such as the construction of a series of hydroelectric dams on the Salween River. If built - at an estimated cost of more than $\$ 5$ billion-the dams will flood an estimated 995 square kilometres of forest. In November 2004, a coalition of Karen non-governmental agencies reported that three-quarters of the 85 villages in the vicinity of the planned dam sites had been forcibly relocated since 1995, displacing tens of thousands of civilians. Thus, the fundamental causes of displacement for many new internally displaced persons in Karen (and Karenni and Shan) areas are related to major new development projects. The typology presented above represents a continuum of (overlapping) 'ideal types', rather than discrete categories of forced migration.

These disturbing developments notwithstanding, since the provisional KNU cease-fire, the situation in other Karen areas has begun to stabilise. In parts of Tenasserim Division, and across much of central and southern Karen State, there is less fighting and somewhat fewer human rights violations than before. In October 2004, the TBBC reported that 'more than half [ 57 per cent] of internally displaced households [had] been forced to work without compensation and... extorted cash or property within the last year'. By October 2005, these numbers had dropped to one-third of those surveyed having paid arbitrary taxes or been subject to forced labour in the past year. In general, therefore, human rights abuses had declined since 2004-at least for those living beyond zones of continuing armed conflict. 
Changing patterns of displacement and rehabilitation

Since 2004 and the provisional KNU cease-fire, large numbers of Type One internally displaced persons in central and southern Karen areas have begun to return 'spontaneously' from hiding places in the jungle (and from relocation sites, and some refugee camps in Thailand) to build more permanent (wooden) houses and grow crops other than swidden rice. Especially in central Karen State, many internally displaced persons have moved from cease-fire zones into relatively more secure villages and peri-urban areas, influenced by the government and armed groups (the KNU controls no cease-fire zones).

As noted above, on receiving relocation orders or becoming subject to other forced migration pressures, some people enter relocation sites while others go into hiding in the jungle, move to other villages (including in cease-fire zones) and/or urban and peri-urban areas. Most relocation sites seem to be disbanded within a few years of their establishment, as the authorities turn a blind eye to forcibly relocated communities' efforts to return to their original land or resettle elsewhere. In many cases, however, conditions in relocation sites return to normalcy (by the standards of rural Burma) over time, as people rebuild their communities in the new location, often in partnership with community based organisations (CBOs) and local non-governmental organisations (NGOs). In such cases, residents could prefer life in the new village to the uncertainties of return or resettlement elsewhere and the possibility of being subject to a new round of displacement in the future. Such rehabilitated relocation sites could offer better health and education services and access to markets than the remote village that people were originally forced to vacate.

In such cases-those in which displaced people come to find the new settlement preferable to their original villages — the label 'relocation site' is not particularly helpful. Certainly, people's vulnerabilities and needs and the options for outside intervention will be different to those of people in classic relocation sites. Thus the importance of a community-based approach to needs analysis, which takes account of local responses to displacement. These distinctions also indicate that 
for many displaced people, rehabilitation in situ (a form of spontaneous rehabilitation) will be a preferred durable solution. These comments notwithstanding, many villagers remain ready to flee at short notice, and still often spend a night under the stars if a tatmadaw patrol approaches the village. Furthermore, many armed conflict-affected (especially border) areas remain heavily mined, with important implications for any future refugee/internally displaced person repatriation or rehabilitation activities.

Type One: responses and impacts

Type One forced migrants' vulnerabilities and consequent needs vary according to their response to displacement pressures. For example, given orders to relocate, villagers could adopt one or more of the following strategies (plus the increasingly difficult and dangerous option of seeking refuge in a neighbouring country)

- hide in or close to zones affected by continuing armed conflict and forced relocation (with the hope of returning home, but often remaining mobile for years)

- move to a relocation site

- enter a cease-fire area

- move to relatively more secure villages, towns or peri-urban areas, including behind the front lines in war zones, in cease-fire zones and in government-controlled locations.

In many cases, civilians from the same community and subject to the same migration pressure (for example, a relocation order) will adopt a variety of different responses. This is often the case within an individual family: elderly people could attempt to stay at home, adults will go into hiding in the jungle, enter a relocation site or seek new livelihood options in relatively more secure and stable villages, towns or urban areas, while some children could be sent to join relatives in town. A displaced family or individual is more likely to adopt a life in hiding, in a zone of continuing armed conflict, if they have some form of pre-established relationship with an armed opposition group—such as relatives already 
living in insurgent-controlled areas, or family or friends in the KNU (for example). Similarly, Type One internally displaced persons will tend to enter a cease-fire area, or relocation site, if they have non-threatening relations with the relevant cease-fire group or state authorities.

Type Two forced migration

Type Two forced migration-that is, state-society conflict-induced displacement-is well illustrated by the situation in cease-fire zones in Kachin and Mon States, where populations are disrupted by military occupation and development activities. Type Three forced migrationlivelihood vulnerability-induced displacement—is discussed here with particular reference to the impact of opium-growing bans in Kokang Special Region One.

Unlike Type One forced migration, Type Two typically comes about after armed conflict has ceased. In Kachin and Mon States, since the agreement to cease-fires between the government and most insurgent groups in the mid 1990s, armed conflict-induced displacement has come to an end (with the exception of some parts of southern Mon State). Other patterns of forced displacement, however, continue. In the past decade, local communities have lost large amounts of land (and associated livelihoods) to confiscation by the Tatmadaw-often in the context of its self-support policy-and by local authorities and business groups, including in the context of development projects and due to unsustainable natural resource extraction. Furthermore, civilians in these areas continue to be subjected to forced labour and other human rights abuses.

Nevertheless, the Kachin Independence Organisation (KIO), New Mon State Party (NMSP) and some other cease-fire groups and their local civil society partners have implemented a range of resettlement, rehabilitation and development programs, despite limited human and financial resources. More could have been achieved with greater government and international financial and capacity-building support. There has, however, been a peace dividend in Kachin and Mon States, and the post cease-fire re-emergence of civil society networks is encouraging. 
The government's attitude towards the Kachin and other cease-fire areas has generally been one of neglect or active obstruction. Kachin leaders claim that the SPDC wants to keep their area underdeveloped and undermine the KIO's standing within Kachin communities. Several other negative developments present worrying precedents in the context of a KNU cease-fire. Although there have been no 'four cuts'-type forced relocations in Kachin State since 1983, communities continue to lose their land. Some eleven tatmadaw battalions in Bhamo District in southern Kachin State, for example, had by 2004 reportedly confiscated 3-4,000 acres of land. Thousands of people have been displaced by large-scale jade-mining around Phakant, in western Kachin State. Increased post cease-fire logging and gold-mining activities have also brought environmental damage to several areas. Finally, the State's leasing of land to private companies often involves land confiscation, as does development-induced displacement_-for example road, bridge and airport construction in the state capital of Myitkyina.

The Mon State case illustrates similar themes. Between 1993 and 1996 — and especially after the 1995 NMSP cease-fire-about 10,000 Mon refugees were forced up to and across the border by Thai authorities. Mon refugees were repatriated to NMSP-controlled cease-fire zones with assistance from international NGOs; the United Nations High Commissioner for Refugees (UNHCR) offered neither protection nor assistance. Some refugees returned home, but most remained in limbo, in camp-like conditions just inside the Burma border, with only limited access to agricultural land. Those Mon who did return home continue to face chronic livelihood and food security problems and remain partially dependent on decreasing humanitarian aid. Meanwhile, as a consequence of continuing human rights abuses (and renewed outbreaks of insurgency) in Mon State, newly displaced villagers continue to seek refuge in the Mon cease-fire zones and refugee resettlement sites.

As in Kachin State, the most serious post cease-fire problems in Mon State relate to housing, land and property rights: since 1998, more than 11,000 acres of farmland have been confiscated by the Tatmadaw. 
Adding insult to injury, farmers have sometimes been forced to work on the confiscated land, building barracks and farming on behalf of the Tatmadaw (Human Rights Foundation of Monland 2003). The building of infrastructure on confiscated land using forced labour has resulted in development-induced displacement.

All of these factors have been causes of continued forced migration since the cease-fire, although the reasons for displacement have changed. In many cases, the abuses outlined above undermine villagers' livelihoods so severely that they have little choice but to migrate.

There have, however, been positive developments in Kachin and Mon States in the past decade. Cessation of armed conflict has generally improved conditions of human security - at least in areas where the ceasefire has held. These truces have brought new opportunities to develop local agriculture and for travel and local trade; they have also created the political and military space for the expansion of civil society networks.

Type Three forced migration

Type Three (livelihood insecurity-induced) internal migration is more widespread than the more acute types of forced migration in Burma (types One and Two). Type Three migrants are not ordered or physically compelled to move by the use or threat of force. They can, however, be described as forced migrants in that they generally have little or no meaningful choice other than to move. This type of movement could be referred to as 'distress migration' or 'migration for survival'. Type Three forced migrants constitute a particularly vulnerable subgroup of the larger economic migrant population.

After a 1989 cease-fire with the government, the Kokang cease-fire zone underwent an economic boom as a result of increased opium harvests and heroin-refining activities. The Myanmar National Democratic Alliance Army (MNDAA) ceasefire group and regional tatmadaw commanders benefitted financially, even if most were not involved directly. The local Kokang and other ethnic minority communities also benefitted somewhat from the opium boom of the 1990s. Most villagers, however, remained very poor and grew opium 
poppies only to fill a rice deficit caused by the poor growing conditions for paddy in the steep Kokang hills.

In 1997, the MNDAA announced a ban on growing and processing opium. This was brought on by a combination of government and international (Chinese and United Nations) pressure- and the example of drugs-free development in neighbouring China. By 2002, the ban had been implemented across much of Kokang. It resulted in farmers' incomes dropping by, on average, 70 per cent, leading to extreme livelihood and human security shocks. Plummeting standards of living have led to health and nutrition crises and rising high school drop-out rates, as well as serious environmental impacts. The humanitarian crisis caused extensive, mostly non-voluntary out-migration to China and the Wa cease-fire areas-where villagers could continue to grow poppies, for a while at least. One-third of the population (estimated at 180,000) reportedly migrated from Special Region One (ceasefire zone) in 2003 after the opium ban.

The hillsides of Kokang are ideally suited to poppy cultivation. Even for those who own land, however, it seems unlikely that this terrain could support more than six to nine months of rice needs. The future looks particularly bleak for the 20-30 per cent of the cease-fire zone population who are not ethnic Kokang. Few Palaung, Miao Tser and Lisu villagers own their own fields, having worked previously as day labourers for Kokang villagers and/or Chinese and other opium entrepreneurs. These communities are finding it particularly difficult to switch to alternative livelihoods. In the event of humanitarian aid being withdrawn, a significant proportion of the population will have little choice but to leave Kokang.

If lessons are not learned from Kokang, the impacts of the opium ban - and resulting vulnerabilities - are likely to be reproduced in zones controlled by the United Wa State Party and elsewhere. One by-product of opium-eradication policies in Wa areas has already been the forcible relocation of some 65,000 villagers from opium-growing areas in the northern Wa sub-state (Jelsma, Kramer and Vervest 2005). 


\section{Humanitarian protection}

Humanitarian, development and political actors' abilities to understand the complexities of forced migration in Burma are particularly important given the evidence from Kachin and Mon States that conflict and displacement did not come to an end with the cessation of insurgency. Kachin and Mon States also indicate the range of projects than can be implemented by local authorities (cease-fire groups) and civil society (CBOs and local NGOs) in the context of less than ideal cease-fires in previously armed conflict-affected areas. More might be achieved with greater support from the government and international agencies.

As noted, since a provisional cease-fire was agreed to between the government and the KNU, the situation in some Karen areas has begun to stabilise. Across parts of lower and western Karen State, there is less fighting and fewer acute human rights violations than before. (Civilians are still, however, subject to a range of abuses, including new problems similar to those experienced post cease-fire in Kachin and Mon States.) These developments raise the subject of displaced people's rehabilitation, including issues of resettlement and return. The primary concern relates to durable solutions_-including aid intervention that links relief and development.

An important set of issues to be resolved relates to the rights of refugees and internally displaced persons to return to and recover their original homes, lands and properties. In June 2005, the UN Sub-Commission on the Promotion and Protection of Human Rights endorsed a set of Principles on Housing and Property Restitution for Refugees and Other Displaced Persons, which reflected international human rights and humanitarian law (UNHCR 2005; Forced Migration Review 2006). The 'Pinheiro Principles' constitute the first consolidated global standard on the housing, land and property rights of the displaced.

Due to the prevalence of refugee-oriented mind-sets, humanitarian and political strategists often assume that all displaced persons want to go home (the equivalent of refugee repatriation, but without the legal protection element). The primary research, however, cautions against 
such assumptions: at least some Type One and other forced migrants could prefer to remain in situ-especially if their concerns for physical security are addressed adequately. Other displaced persons will want to resettle elsewhere-either returning home or moving to a new location-especially if sustainable solutions are found to long-running armed and state-society conflicts in Burma.

The durable solution of local integration could allow internally displaced persons to escape cycles of displacement and begin to rebuild their lives. Whether they want to stay in their present settlement or return to a previous home will in part depend on their current state of livelihood and human security in situ-for example, whether they have found at least semi-durable solutions to their plight. Another important factor will be their knowledge of what has happened to their old homes, land and other property, and whether these have since been occupied-by the State or the Tatmadaw (or other armed group), by private commercial interests (often linked to state or para-state agencies) or by other civilians (secondary occupants - quite possibly, other internally displaced persons). As in refugee repatriation, the principle of informed voluntariness should be central to any decisions regarding solutions to internal displacement in Burma.

The protection of internationally agreed rights is first and foremost the responsibility of states. Not all states, however, are signatory to all aspects of international law. The Burmese government has not ratified the instruments of the UNHCR or the International Covenant on Economic, Social and Cultural Rights. In cases such as Burma, where the State is unwilling or unable to protect its citizens, this responsibility falls on the international community. Some international agencies (for example, the UNHCR, UNICEF and the International Committee of the Red Cross) are tasked specifically with protecting certain rights, or categories of people. In addition, the United Nations has a mandate to protect and promote human rights.

At its broadest, the notion of humanitarian protection includes securing access to the right to life (for example, physical security and the 
rights to shelter, food and water). This could take the form of material aid (substitution mode) supplied directly to the target population-for instance, the distribution of rice by the World Food Program to communities that have suffered as a result of opium bans in Shan State. Humanitarian actors could also work in partnership with state or nonstate actors to deliver goods and services. For example, UNICEF supports the SPDC ministries of health and education by providing training to staff and funding the acquisition and distribution of medicines (including vaccination campaigns) and teaching materials. Other international donors support local Burmese NGOs and CBOs to provide a range of services to displaced populations in Burma-often in conflict-affected areas that are beyond the reach of international agencies.

Humanitarian assistance alone tends to be responsive or remedial in nature. This mode of intervention is often, however, insufficient to alleviate suffering and protect human dignity, because it does not address the underlying causes of distress. The concept of protection implies prevention, which in turn draws attention to the reasons for deprivation. It is often necessary to address the actors and structures that cause violence and suffering; however, in a constrained working environment such as Burma, it is easier to focus on service delivery and relief activities than on more politically challenging issues such as protection. There is a danger that power-holders (including especially the State) could withdraw access to vulnerable populations. This access is necessary in order to deliver assistance, should the humanitarian actor seek to engage power-holders on these issues.

Therefore, one of the greatest challenges facing international agencies in Burma is how to achieve a balance between short and longer-term assistance interventions, while keeping a focus on protection concerns. 'Assistance versus protection' is not a zero-sum game: where assistance access is possible, often forms of protection can also be provided. By employing a range of strategies, including supporting the practices of affected communities, it is often possible to address protection concerns in the process of meeting other basic needs. 


\section{Advocacy}

According to Slim and Bonwick

...advocacy is a core area of protective practice for both humanitarian and human-rights agencies. It is about convincing decision-makers to change...It encompasses everything from persuading the village chief to allocate land to displaced families to influencing a senior General on the conduct of his army (2005:84).

Humanitarian advocacy aims to protect civilians from-or alleviate the impacts of-abuse. Such action falls under three broad modes: denunciation, mobilisation and persuasion ('responsibalisation').

Some agencies_-primarily human rights-oriented groups based outside the country-denounce the violation of basic rights involved in forced displacement and call for fundamental changes in Burma, or at least radically improved behaviour on the part of the State and armed groups. In most cases, their recommendations are very general, with few attempts to seriously consider how suggestions might be achieved in practice. In general, those who are affected most by armed conflict and cease-fires have the least ability to influence such public advocacy agendas — they are denied a 'voice' — in comparison with relatively welleducated urban and political élites and are rarely consulted in setting advocacy goals and messages regarding their plight.

Organisations working in government-controlled Burma cannot afford to be as bold in their advocacy roles as those in Thailand and overseas; however, the presence of humanitarian personnel in conflictaffected areas can help to create a 'humanitarian space' in which to engage in behind-the-scenes advocacy. A consciously adopted and visible protective presence could constrain local power-holders' opportunities for abuse, because authorities worry that information regarding violations will be communicated to the international community and/or because the presence of a witness 'shames' them into adopting better behaviour. This is a persuasive mode of advocacy.

This is an area in which UN agencies and the International Committee of the Red Cross (ICRC) have made some progress in 
the past few years. Confidential advocacy with national, state and local authorities has helped to build a more protective environment, especially in the fields of harm reduction and HIV/AIDS issues, trafficking and child rights. Examples include the establishment of an interagency-government committee to stop recruitment and facilitate demobilisation of child soldiers and ICRC and UNHCR training programs for police and other government employees. The advocacy activities of the ICRC - including its confidential referral of cases of human rights abuse to the authorities-also gives some leverage to progressive elements within the government and state agencies, who wish to establish better practice in their fields.

Some UN agencies have specific, and therefore rather restricted, protection mandates. For example, UNICEF has made progress in a number of protection sectors, with the government recognising child protection concerns and implementing new initiatives. Indeed, UNICEF (2005) has been able to persuade the government that more strategic approaches are required to 'reach the unreached'-for example, focusing in the education sector on 'the most vulnerable, including poor, minority and out-of-school children, children living in remote areas, and children from migrant and mobile populations'. The ICRC's protective presence in areas of continuing armed conflict has also been quite effective, at least until it had its access significantly curtailed in 1995.

Some civil society groups with programs inside Burma have also mobilised agencies operating in persuasive or denunciation modes. For example, $\mathrm{CBO}$ s in rural areas could pass on human rights information to their local and international counterparts in Yangon or Thailand. There is evidence that the existence of such protection and advocacy networks has served to reduce the incidence of human rights abuses in some parts of Karen and Karenni States. Most international (and especially UN) agencies inside Burma, however, demonstrate only limited awareness of protection issues, and undertake minimal advocacy activities on behalf of displaced persons. As a senior UN officer explained to the author, 
'In general, and with some important exceptions, there is a lack of a "culture of protection" within the UN, especially at the field level.'

In December 2005, the UN Inter-Agency Standing Committee assigned to the UNHCR primary responsibility for leading a cluster of agencies in coordinating assistance to and the protection of the estimated 20-25 million internally displaced persons world-wide (Forced Migration Review 2006). It is hoped that in the next two years adoption of the new cluster will prompt international agencies to address gaps in responses to internally displaced person crises in Burma.

Restrictions on humanitarian space

The ability of local and international agencies to address Burma's protracted and interrelated displacement crises is in large part determined by the amount and quality of political and humanitarian 'space' available. The period from November 2003 to September 2004 was one of rapidly opening humanitarian space in Burma. In part, the authorities' willingness to allow international access to previously outof-bounds areas was a response to increased pressure after the 'Depayin Massacre' of 30 May 2003.

Since October 2004 and the demise of Khin Nyunt and colleagues, along with their relatively progressive ideology, the extent and quality of political and humanitarian space in Burma has declined. For humanitarian agencies, this constriction is reflected in a set of draft Guidelines for UN Agencies, International Organizations and NGO/ INGOs on Cooperation Program in Myanmar produced by the Ministry of National Planning and Economic Development office in February 2006. Some of its more worrying proposals include that state officials should accompany UN and international NGO staff on all field trips; the proposed supervisory roles are to be played by central, state-divisional and township coordinating committees (including roles for the Union Solidarity Development Association and various government-operated NGOs); and the government plans to vet all new Burmese staff of the United Nations and international NGOs. 
It seems likely that, should these regulations be implemented systematically, some international agencies will withdraw from the country. Already the Global Fund for HIV/AIDS, Malaria and Tuberculosis has ceased operations in Burma—although in this case there were additional, politically driven considerations behind the decision to leave. In February 2006, Médecins sans Frontières (MSF) also withdrew from Burma, claiming that increased government restrictions imposed since 2005 had made its operations in Mon and Karen States untenable. As MSF avoids working with local state structures, and thus does little to build local capacities, it was ill-prepared to operate in an increasingly constricted humanitarian environment.

A further consequence of the restrictive operating environment in Burma is that most international agencies have very limited access to the upper echelons of the military government, and are unable to engage in policy dialogue with, or communicate advocacy messages to, the regime. Nevertheless, given these increasingly bleak and repressive conditions, the United Nations in particular has a special responsibility to advocate and act on behalf of the most vulnerable, conflict-affected populations.

\section{Conclusions}

This chapter has described aspects of forced migration in Burma that are under-researched, including the phenomenon of serial displacement, and has proposed a three-part typology. Many internally displaced persons and others move repeatedly, sometimes for a combination of reasons; others have been displaced for some time and have found at least semi-durable solutions to their plight; many are living mixed with communities who are not—or have not recently been—displaced. Forced migrants' needs can be assessed and appropriate interventions planned only if the full complexity of displacement situations in Burma is understood. Humanitarian (and political) actors should therefore respect and respond to the voices and agency of forced migrants and enrol their participation in all aspects of program planning and 
implementation. In most cases, forced migrants and communities threatened by displacement have special protection vulnerabilities related to the causes of migration (especially armed and state-society conflict). These concerns link humanitarian needs to explicitly political issues. Ultimately, substantial and sustained protection from forced migration, as well as the rehabilitation of displaced populations and reconstruction of communities, depends on resolutions to the conflicts that cause displacement in Burma. Unfortunately, efforts at conflict resolution have thus far met with only limited success.

\section{Notes}

1 The 'Pinheiro Principles' are the United Nations' Principles on Housing and Property Restitution for Refugees and Displaced Persons, which were prepared by the United Nation's Special Rapporteur, Professor Paolo Sergio Pinheiro, and adopted by the United Nations in August 2005. They have been published by the Centre on Housing Rights and Evictions (COHRE).

\section{References}

Amnesty International, 2002. Myanmar: lack of security in counterinsurgency areas, Amnesty International, London.

_, 2004 . Myanmar — the Rohingya minority: fundamental rights denied, Amnesty International, London.

— 2005. Thailand: the plight of Burmese migrant workers, Amnesty International, London.

Burma Ethnic Research Group and Friedrich Naumann Foundation, 1998a. Forgotten Victims of a Hidden War: internally displaced Karen in Burma, Burma Ethnic Research Group, Chiang Mai. Available from http://www.ibiblio.org/obl/docs3/Berg-Forgotten_Victims.pdf

Bamforth, V. Lanjouw, S. and Mortimer, B., 2000. Conflict and Displacement in Karenni: the need for considered responses, report prepared for the Burma Ethnic Research Group, Chiang Mai.

Burma Issues, 2003. After the 1997 Offensives: the Burma Army's relocation program Kamoethway Area, Tenasserim Division, The Peace Way Foundation, Bangkok. 
Callahan, M., 2003. Making Enemies: war and state building in Burma, Cornell University Press, Ithaca, New York.

Caverzasio, S.G. (ed.), 2001. Strengthening Protection in War: a search for professional standards, International Committee of the Red Cross, Geneva.

Cusano, C., 2001. 'Burma: displaced Karens: "Like water on the Khu Leaf"', in M. Vincent and B.R. Sorensen (eds), Caught Between Borders: response strategies of the internally displaced, Pluto Press for Norwegian Refugee Council, Oslo.

Free Burma Rangers, 2006. Map of Burma Army Attacks in Northern Karen State, 28 June.

Grundy-Warr, C. and Wong, E.S.Y., 2002. 'Geographies of displacement: the Karenni and the Shan across the Myanmar-Thailand border', Singapore Journal of Topical Geography, 23(1):93-122.

Heidel, B., 2006. The Growth of Civil Society in Myanmar, Books for Change, Bangalore.

Heppner, K., 2005. Sovereignty, survival and resistance: contending perspectives on Karen internal displacement in Burma, Karen Human Rights Group Working Paper, Karen Human Rights Group, Bangkok.

Humanitarian Affairs Research Project, 2003. Running the Gauntlet: the impact of internal displacement in Southern Shan State, Asian Regional Centre for Migration, Chulalongkorn University, Bangkok.

Human Rights Foundation of Monland, 2003. No Land to Farm: a comprehensive report on land, real estate and properties confiscation in Mon's Area, Burma (1998-2003), Human Rights Foundation of Monland, Bangkok.

Human Rights Watch, 2005. '"They Came and Destroyed Our Village Again": the plight of internally displaced persons in Karen State', Human Rights Watch Report, 17(4), January. Available from: http:// hrw.org/reports/2005/burma0605/burma0605.pdf.

Jelsma, M., Kramer, T. and Vervest, P. (eds.), 2005. Trouble in the Triangle: opium and conflict in Burma, Silkworm Books, Chiang Mai.

Karen Rivers Watch, 2004. Damming at Gunpoint: tatmadaw atrocities pave the way for Salween Dams in Karen State, Karen Rivers Watch, Chiang Mai.

Lang, H., 2002. Fear and Sanctuary: Burmese refugees in Thailand, Cornell, Ithaca. 
Mon Language Literacy Training Course, 2005. (unpublished) '2005 report', The Mon Literacy Training Course Organizing Committee, August.

Shan Human Rights Foundation, 2003. Charting the Exodus From Shan State, Shan Human Rights Foundation, Chiang Mai.

Sherman, J., 2003. 'Burma: lessons from the ceasefires', in J. Ballentine and K. Ballentine (eds), The Political Economy of Armed Conflict: beyond greed and grievance, Rienner, Boulder.

Slim, H. and Bonwick, A., 2005. Protection: a guide for humanitarian agencies, Active Learning Network for Accountability and Participation and Overseas Development Institute, London.

Smith, M., 1999. Burma: insurgency and the politics of ethnicity, Zed Books, London.

South, A., 1994. 'Political Transition in Burma: a new model for democratisation', Contemporary Southeast Asia, Institute of Southeast Asian Studies, Singapore.

__, 2005. Mon Nationalism and Civil War in Burma: the golden sheldrake, Routledge, London.

Taylor, R., 1985. 'Government responses to armed communist and separatist movements: Burma', in C. Jeshurun (ed.), Governments and Rebellions in Southeast Asia, Institute of Southeast Asian Studies, Singapore.

— 1987. The State of Burma, Hurst, London.

Thailand Burma Border Consortium, 2004. Internal Displacement and Vulnerability in Eastern Burma, Thailand Burma Border Consortium, Bangkok.

__ 2005a. Program Report, Thailand Burma Border Consortium, Bangkok.

- 2005b. Internal Displacement and Protection in Eastern Burma, Thailand Burma Border Consortium, Bangkok.

—_, 2006. Burmese Border Refugee Sites With Population Figures 2005, Thailand Burma Border Consortium, Bangkok.

Thant Myint-U., 2001. The Making of Modern Burma, Cambridge University Press, Cambridge.

UNHCR, 1998. The Guiding Principles on Internal Displacement, E/CN.4/1998/53/Add.2, United Nations High Commissioner for Refugees, Geneva. 
—, 2005. Principles on Housing and Property Restitution for Refugees and Displaced Persons, E/CN.4/Sub.2/2005/17, United Nations High Commissioner for Refugees.

UNICEF, 2005. The Situation of Women and Children in Myanmar, Country Program Document, Yangon.

Acknowledgments

Research was conducted during consultancies for the Thailand Burma Border Consortium (2002), International Crisis Group (2003), Human Rights Watch (2004-05), United Nations Development Programme (2005) and with a grant from the John D. and Catherine T. MacArthur Foundation (2003-04). Special thanks for help with research and writing to Monique Skidmore, Julie Belanger, Alan Smith, Martin Smith, and to many friends and colleagues in and from Burma. A version of this chapter was published by the Refugee Studies Centre (Oxford University) in February 2007 (RSC Working Paper No. 39). 